\title{
村脇義之 学位論文審査要旨
}

$\begin{array}{ccccc}\text { 主查 } & \text { 清 } & \text { 水 } & \text { 英 } & \text { 治 } \\ \text { 副主查 } & \text { 池 } & \text { 口 } & \text { 正 } & \text { 英 } \\ \text { 同 } & \text { 汐 } & \text { 田 } & \text { 剛 } & \text { 史 }\end{array}$

\section{主論文}

Aberrant expression of selenoproteins in the progression of colorectal cancer （大腸癌進展過程におけるセレノプロテインの発現異常）

（著者：村脇義之、土谷博之、神戸貴雅、原田賢一、八島一夫、野坂仁愛、谷田理、 河野通盛、向山智之、西向栄治、古城治彦、松浦達也、高橋和彦、尾崎充彦、 井藤久雄、淀井淳司、村脇義和、汐田剛史）

平成20年1月 Cancer Letters 第259巻 218頁～230頁 


\section{学 位 論 文 要 旨}

\section{Aberrant expression of selenoproteins in the progression of colorectal cancer （大腸癌進展過程におけるセレノプロテインの発現異常）}

大腸癌の発症・進展の要因に、活性酸素種（ROS）による酸化ストレスの関与が知られ、 DNAや細胞内分子の酸化障害が腫瘍進展を促進すると考えられている。セレン含有蛋白であ り抗酸化作用を有するグルタチオンペルオキシダーゼ (GPX)などは、種々の癌での発現異常 が報告されている。本研究は大腸癌の進展過程における酸化ストレスの影響とグルタチオ ンペルオキシダーゼ (GPx)、チオレドキシンリダクターゼ (TXR)、セレノプロテインP (SePP) などのセレン含有抗酸化蛋白であるセレノプロテインの役割を明らかにするため、酸化ス トレス関連分子の発現をヒト大腸癌組織で検討した。その結果大腸癌組織では酸化ストレ スが充進しており、一因として抗酸化セレノプロテインの発現低下が示唆された。

\section{方 法}

2004年から2006年に鳥取大学医学部附属病院の関連病院にて加療された 41 症例の大腸癌 手術症例を対象とした。このうち2例は潰瘍性大腸炎関連大腸癌である。手術後に癌部、非 癌部の組織を別々採取し、酸化ストレス関連分子を免疫組織染色、ウエスタンブロット(WB) 法、グルタチオン定量により検討した。また無作為に選しだ5大腸癌症例より腺腫部分の免 疫組織化学染色を行った。酸化ストレスの検討分子は、8-ヒドロキシグアノシン $(8-0 \mathrm{HdG}) 、$ 4-ヒドロキシノネナール (4-HNE) 、4-ヒロドキシへキセナール (4-HHE)、マロンジアルデヒ ド(MDA)、GPx-1、GPx-2、GPx-3、SePP、TXR、チオレドキシン(TRX)、スーパーオキシドジ スムターゼ-1 (SOD-1)、カタラーゼ (CAT)、GSH、酸化型GSH (GSSG)である。細胞増殖、アポ トーシス、p53発現についてはPCNA染色、TUNEL法、p53染色にて検討した。臨床パラメータ ーとして年齢、性別、臨床病期、Dukes分類、CEA、CA19-9を検討した。

免疫組織化学染色のp53、PCNA、TUNEL、8-0HdGは1 mm² あたりの陽性細胞数で評価した。 $\mathrm{GPx}-1 、 \mathrm{GPx}-2 、 \mathrm{GPx}-3 、 \mathrm{SePP} 、 \mathrm{SOD}-1 、 \mathrm{TRX} 、 T X R の$ 染色は分布と発現強度のスコア化にて評 価した。

WB法は4-HNE、4-HHE、MDA、SOD-1、GPx-1、GPx-2、CAT、SePP、TRX、TXRについて行い、 発現強度はImageJ1.30vにて測定後 $\beta$-actinに対する比で表示した。

大腸組織中のGSHとGSSG量はTotal Glutathione Quantification Kitを用い13症例で定量 
した。

\section{結 果 と考 察}

免疫組織化学染色では、p53、PCNA、TUNEL陽性細胞は癌組織で非癌部に比べて有意に増 加していた。酸化的DNA障害のマーカーである8-OHdG、過酸化脂質関連蛋白である4-HNE、 MDA、4-HHEは癌部で非癌部に比較して有意に増加しており、大腸癌組織では正常細胞に比 ベて酸化ストレスが増加していることが示された。セレン久乏に感受性の高いセレノプロ テインである $\mathrm{GPx}-1 、 G P x-3 、 S e P P の$ 発現は有意に低下していたが、セレン久乏に抵抗性の 高いGPX-2は増加していた。SOD-1発現は癌部でわずかであるが、有意に増加していた。 8- $0 H d G$ や過酸化脂質関連蛋白の発現と病期の進展との間に明らかな関連は認めなかった。 潰瘍性大腸炎関連大腸癌も GPx-1、GPx-3、SePPの発現は低下していたが、GPx-2は増加して いた。これらの結果は通常の大腸癌、潰瘍性大腸炎関連大腸癌は共にセレノプロテインの 発現異常が酸化ストレス発生に重要であることを示唆している。腺腫では、GPx-1、GPx-2、 GPX-3、SePP、SOD-1、TRX, CAT、TXRについて非癌部と発現レベルに変化を認めなかった。

WB法における4-HNE/ $\beta$-actin、MDA/ $\beta$-actinは癌部で有意に増加していた。また 4-HNE/ $\beta$-actinはMDA/ $\beta$-actinや8-OHdG陽性細胞と正の相関関係を示した。GPx-1/ $\beta$-actin とSePP/ $\beta$-actinは癌部で非癌部に比べて低下していた。SePP/ $\beta$-actinは臨床病期stage II に比べて stageIII とstageIVで低下しており、大腸癌の進展とともに低下する傾向を示した。 一方、GPx-2/ $\beta$-actinは癌部で非癌部に比べて有意に増加し、4-HNE/ $\beta$-actinやMDA/ $\beta$-actin と正の相関を示した。GSHは癌部で非癌部に比較して低下していた。またGSSG/GSHは癌部で 低下傾向を示した。2例の潰瘍性大腸炎関連大腸癌患者は、癌部において通常の大腸癌と比 べ、GPx-1、SePPの蛋白発現は低下し、GPx-2の蛋白発現は上昇する傾向を認めた。

\section{結 論}

大腸癌組織では酸化ストレスが亢進していた。一要因として、GPx-1、GPx-3、SePPなど のセレン含有抗酸化蛋白の発現が減少し、大腸癌の進展に関与していることが示唆された。 